\title{
Implementation of Product Model, Price, Place, Promotion in Improving Noken Sales (OAP)
}

\author{
Semuel Batlajery ${ }^{1 *}$, Marlyn E. Alfons ${ }^{2}$ \\ 1,2 Faculty of Economics and Bussines, Musamus Merauke University, Indonesia
}

\section{A R T I C L E I N F O}

Article history:

Received 13 October 2020

Received in revised form

12 November 2020

Accepted 18 February 2021

Available online 25

February 2021

Keywords:

Marketing Mix, Sales, SMEs

\begin{abstract}
A B S T R A C T
This study aims to analyze the Application of Products, Prices, Places, Promotions in Increasing Papua Noken Sales. A qualitative / descriptive or narrative approach in this study. Primary data is direct data from the Noken seller. Secondary data, namely indirect data from informants from brochures, magazines, and others. Data collection techniques: Observation, namely observing the object / place of research. Interviewing is conducting a series of questions and answers to informants who know best about the object of research. The questionnaire contains structured questions to informants. The informants in this study were 5 Yanti Noken and Syria Noken. This study shows that application of Product, Price, Place, Promotion for Noken sales in increasing revenue, models that must be applied: Application of Product Strategy Models, Application of Price Strategy Models, Application of Place Strategy Models, Application of Promotion Strategy Models. The four models must be worked on together because these models are interrelated. In this model, promotion in the midst of the Covid-19 pandemic is the most effective. Promotion that must be done by salespeople, especially through the online social media (Facebook). The seller must be responsible for delivering the order to the customer's place. The implementation of this Promotion Strategy Model must be carried out, in order to increase income, particularly the Merauke buying and selling forum. The price must be affordable according to the pockets of the community, and still listen to government advice to stay at home and keep the distance.
\end{abstract}

Copyright (C) Universitas Pendidikan Ganesha. All rights reserved.

\section{Introduction}

The development and growth of Small and Medium Enterprises (SMEs) in Indonesia are growing rapidly, this makes business people involved in the business world must be more creative and innovative in formulating the right marketing strategy (Finoti et al., 2017; Prawita et al., 2017). Marketing is the essence of business life. Business actors must be more observant and thorough in reading opportunities and making new strategies or ways to design marketing strategies that are reliable and tough in the midst of intense market competition. This was exacerbated by the Covid-19 pandemic that hit the world and even Indonesia did not escape from the Covid-19 itself (Hadiwardoyo, 2020).

This pandemic is not only a disaster for human health but also causes chaos in the economic sector (Yamali \& Putri, 2020). Not only for large industries, but making SMEs in Indonesia nervous. This makes Indonesia experience a decrease in the percentage of economic growth of $0.1 \%$ in the SME sector. Then the model offered to increase sales to small and medium enterprises (SMEs) is stated in the 4P marketing strategy: Product, Price, Place and Promotion (Borden, 1964; Gronroos, 1994). So the application of the Marketing Mix or what is known as 4p Product, Price, Place, Promotion is a good model to be applied to businesses both large and small scale to increase sales (Lahtinen, et al., 2020; Rahmani et al., 2015). So companies are willing to spend a lot of money to design strategies to increase sales. The $4 \mathrm{p}$ marketing strategy is a current tactical marketing model which consists of product, price, place of promotion which is an integrated unit to generate responses from the public (Silverman, 1995; Thabit \& Raewf, 2018). 
Marketing management as the art and science of choosing target markets and getting, keeping, and growing customers through delivering and communicating superior customers value (Abdurrahman, 2015; Rosad, 2015). Marketing management is the art, process and science of selecting the right target market, retaining customers, creating value, delivering and communicating good selling points in the eyes of superior consumers (Braciníková \& Matušínská, 2017; Denziana \& Yunggo, 2017). The problems that occur in SMEs are still lack of knowledge in adjusting or applying in building a marketing mix or 4P strategy concept (Dominici, 2009; Kalyanam \& McIntyre, 2002). Every element of Product, Price, Place, Promotion is related and influences one another. So that it needs to be applied in small and medium enterprises. Even though this 4P is very good, if it is applied properly it will be able to help the sales increase (Mukarromah, 2018; Yun-sheng, 2001).

The problem that occurs in SMEs that selling Noken is a lack of knowledge in implementing the $4 p$ Strategy Model (Product, Price, Place, Promotion). So it needs to be applied to SMEs that sell Noken, if implemented properly, it can help increase the sales. Product (Produk) is all about the value of the products offered to the public so that it can be seen, held, felt, purchased to meet the needs. Products can be classified as quality, quality, design, brand, service, in order to get responses from the public (Constantinides, 2006). Price (harga), which is the amount of money used to buy a product. Prices include prices, discounts, and others (Borden, 1964; Finoti et al., 2017). Place (Tempat), namely various activities carried out by small and medium enterprises to produce various products for sale and available in the market. Places include strategic places, products are available when people need them, and products reach consumers (Asdi \& Putra, 2020). Promotion (Promotion) that the various activities undertaken by the seller to communicate, introduce their products to consumers. Promotion includes promotion through mass media, Facebook, web, brochures, billboards, word of mouth (Antonella, 2017). The marketing mix includes four (4) main things and can be controlled by the company which includes product, price, place and promotion (Amstrong, 2016).

Survey results on problems that occur in the business of selling Noken to Indigenous Papuans (OAP) are very concerned, due to the lack of knowledge about the product, especially in terms of design that does not attract consumer interest, the price set by the Noken seller is rather high, the seller's place is strategic which is on the edge of the main road, making it easier for passers-by to buy Noken directly, promotions so far have not been carried out properly by sellers, especially those who upload them on the Merauke buying and selling forums and others. otherwise, sales will decline. This is supported by sales data in the Table 2.

Table 1. Noken Sales Data

\begin{tabular}{|c|c|c|c|c|}
\hline Month & Name of Goods & Total & Unit Price of & Revenue \\
\hline August & Mahkato & 8 & 300,000 & $2,400,000$ \\
\hline September & $\begin{array}{l}\text { Noken yarn woll } \\
\text { Noken Bulu }\end{array}$ & 4 & 250,000 & $1,000,000$ \\
\hline October & Kaswari & 5 & 150,000 & 750,000 \\
\hline November & $\begin{array}{l}\text { Noken yarn woll } \\
\text { Bracelet + woll }\end{array}$ & 6 & 100,000 & 600,000 \\
\hline December & $\begin{array}{l}\text { Noken } \\
\text { Noken from aloes }\end{array}$ & 4 & 175,000 & 700,000 \\
\hline January & skin & 6 & 300,000 & $1,800,000$ \\
\hline February & Noken from bark & 3 & 150,000 & 450,000 \\
\hline March & - & & & - \\
\hline April & - & & & - \\
\hline May & - & & & - \\
\hline $\begin{array}{l}\text { June } \\
\text { July }\end{array}$ & $\begin{array}{l}\text { Noken thread woll } \\
+ \text { crown } \\
\text { Noken cassowary } \\
\text { fur + yarn woll }\end{array}$ & 5 & 550,000 & $2,750,000$ \\
\hline
\end{tabular}

Based on this table, sales data for the months of August, September, October, November, December 2019 have fluctuated. Whereas January, February there were purchases, but on March 3, April, May 2020 there were no purchases because Covid-19 attacked Indonesia and even spread to Merauke City. After the government opened Lockdown, sales increased in June and July 2020. The Covid-19 pandemic has had a huge economic impact on small and medium enterprises (SMEs) to maintain their survival. However, the impact of this virus is also an opportunity for small and medium enterprises 
(SMEs) to create their own business opportunities that can innovate from offline to online. to keep sales going. Today's shopping behavior all leads to services online to meet needs and reduce transactions offline. Thus, this study aims to analyze the Application of Products, Prices, Places, Promotions in Increasing Papua Noken Sales for Indigenous Papuans (OAP).

\section{Methods}

The research was carried out from August to September 2020. This study was a qualitative with descriptive or narrative approach. Primary data is direct data from the Noken seller. Secondary data, namely indirect data from informants from brochures, magazines, and others. Data collection techniques that used in this study is observation, namely observing the object / place of research. Interviewing is conducting a series of questions and answers to informants who know best about the object of research. The research instrument in this study was a questionnaire that contains structured questions to informants. The informants in this study were Yanti Noken and Siria Noken Ivone Noken, totaling 5 people. Processing and data analysis used in this study is to conduct a SWOT analysis of the internal environment's strengths and weaknesses, while the external environment is the opportunities and threats faced by the Noken seller. Then the data were analyzed using explanations in the form of sentences.

\section{Results and Discussions}

\section{General}

Description The general description of the establishment of Yanti Noken, Siria Noken and Olivia Noken were formed not standing simultaneously. Yanti Noken was founded in 2017, Siria Noken was founded in 2016 and Olivia Noken was founded in 2017. These three small businesses, their activities every day sell various types of Noken ranging from bracelet trinkets, small to large Noken bags. This type of sale is a cash gift from Merauke Regency, known as the City of Deer. This Noken selling place is on Jalan Brawijaya, Merauke Regency.

\section{Descriptions of respondents}

Table 2. Informants by Gender

\begin{tabular}{clccc}
\hline No. & & Age & Total & Percentage $\%$ \\
\hline 1 & Male & & 1 & 14 \\
2 & Women & 6 & 86 \\
\hline \multicolumn{2}{r}{ Total } & $\mathbf{7}$ & $\mathbf{1 0 0}$ \\
\hline
\end{tabular}

Based on informant data in the Table 2, dominant women are 86\%. Meanwhile, $14 \%$ of males, thus in this study were dominated by females

Table 2. Informants by Age

\begin{tabular}{cccc}
\hline No & Gender & Total & Percentage\% \\
\hline 1 & $21-30$ Years & 2 & 29 \\
2 & 31- 40 Years & 3 & 50 \\
3 & 41- 50 Years & 2 & 29 \\
\hline & Total & $\mathbf{7}$ & $\mathbf{1 0 0}$ \\
\hline
\end{tabular}

Based on the descriptions of the informants in the Table 3, that is, the ages of 31-40 are 03 people with a percentage of 50\%, ages 21-30 are 02 people with a percentage of 29\%, ages 41-50 are 02 people with a percentage of $29 \%$, thus the ages of $31-40$ more years with a percentage of $50 \%$.

\section{Results of Research on Application of Models Product, Price, Place, Promotion}

From the results of the analysis of Noken sales to (OAP) Indigenous Papuans. problems with indigenous Papuans and how to overcome them, namely how to model products, prices, places, promotions to be applied to the Noken sales business so that products are in accordance with consumer desires, prices must be affordable, places must be available, and promotions must be online so that consumers can reach them. Product (Product) with the various types of Noken sold by Noken sellers, yanti 
Noken, siria Noken, and ivone Noken have not been able to reach consumers well, so the activities carried out by Noken sellers have not been maximized:

Based on the results of interviews with several informants as follows: Services provided by Yanti Noken, Siria Noken, and Ivone Noken, have been very good in terms of communication with customers, namely with raw material providers, then the shortcomings of these small businesses are still buying Noken from neighboring Papua New Guinea. Activities carried out by Yanti Noken, Siria Noken, and Olivia Noken. In fact, their products are often sent to Jakarta for national events. However, the resulting product does not really attract consumer interest, because of its design. This is supported by the theory according to (Amstrong, 2016) which states that a product is anything that can be offered to the market to meet wants or needs. Human Resources Yanti Noken, Siria Noken and Ivone Noken are on average with high school education, this can be seen from Yanti Noken, Siria Noken and Olivia Noken employing employees to look after and provide services to buyers. This Noken sale is often invited everywhere to take part in exhibitions at every activity. So that service and communication are maintained so that the continuity of this business can still exist.

Price (Harga) The price set by the Noken seller varies, ranging from 800,000 to 100,000 . According to the seller, this price already takes into account raw materials and transportation costs, so that the price is set according to the consumer's pocket. from the survey results to several customers that the price is still affordable. This is supported by (Kartini, 2014; Sudari et al., 2019; Van Waterschoot \& Bulte, 1992), namely: price according to quality. Prices according to facilities. An affordable price. Prices are set according to the benefits obtained.

Place (tempat) greatly influences buyers, because a strategic place can increase sales. From the survey results where the three Noken sales are already in a strategic place, making it easier for customers to stop buying, this can be seen from each month the purchase of Noken continues to increase, only 3 (three) months the period lockdown sales has decreased. This is reinforced by the theory: According to (Wang et al., 2005) defines a location as a place where a company must be headquartered and carry out operations. So the location here is a place where a type of business or line of business will be carried out.

Promotion (Promosi) promotion is very important to influence consumers, because through the promotion of products will be sold. This is the impact of the Covid-19 pandemic which demands sellers to innovate from offline to online. Thus limiting community activities to stay at home. From the results of their survey, there were sales online, especially through Facebook, but they did not take advantage of it because they lacked energy, so no one delivered the results of their purchases. These results are supported by (Abdurrahman, 2015) that promotion is a means used by companies in an attempt to inform, persuade and remind consumers directly or indirectly about the products and those they sell.

\section{Strategy for Implementing Models Product, Price, Place, Promotion}

Strategies that must be applied by Noken sellers, namely by applying the strategic model Product, Price, Place, Promotion very well and efficiently. Noken products have a good value in the eyes of the community, because they are used everywhere. Noken has the advantage of storing cellphones, wallets, etc. as well as replacing plastic bags. The service provided by the sale of Noken is very good, this can be seen from the results of a survey according to Yanti Noken who said that orders for crowns, knick-knacks for the needs of the big day. responsive seller prepares to order. So that must be maintained.

The prices of various types of products sold by sellers vary widely, ranging from 100,000 to 800,000 one hundred thousand to eight hundred thousand. Based on the survey results, the price of Noken has been set affordable by the pockets of the community. Yanti Noken. Sirian Noken and Ivone Noken are in a strategic place, where the three of them are on the side of the highway, making it easier for consumers to stop by to buy. Sales made by Yanti Noken, Siria Noken and Ivone Noken are still offline, this must be done well, because the Covid-19 pandemic like this is required by sellers to sell products online, especially those with web and facebook, so we can anticipate Covid-19. Promotion has been carried out by Yanti Noken, who already has a forum on Facebook, but if there is an online order there is no power to deliver it to where the consumer is, this must be pursued in the future so that all consumers are served. Meanwhile, Siria Noken and Ivone Noken have limited online access knowledge, this is necessary to learn in order to reach consumers who buy them.

\section{Discussion}

Activities that will be carried out by selling Noken starting from Yanti Noken, Siria Noken, Ivone Noken in marketing products, it is necessary to apply the Product Model, Price, Place, Promotion. Then the seller knows the environmental analysis Internal Strengths / weaknesses. External Opportunities / Threats, then the seller is obliged to use a SWOT analysis as follows: 


\section{Strength (Strength)}

The strength in sales was excellent especially the camshaft on the edge of the highway, it is easy for consumers / people to buy.

\section{Weakness (Weakness)}

Noken sales weakness is not good parking place for shoppers to park on a side street, because it would interfere with the activity of Yanti Nokens umum.Kekurangan transport, existing campaign via online (mainly selling Merauke) but not used, ie if There is already an order which means that Yanti Noken must be responsible for delivering the goods to where the consumer is located.

\section{Opportunity (Opportunity)}

Noken sales opportunities is very good because every activity holidays like carnival, August 17, the State official visits, order camshaft, crown, and others surely soar. Sales of Noken are expected to use online promotions because they are very efficient, especially the government's recommendation to stay at home to avoid Covid-19. utilize it online, especially selling and buying Merauke. personnel must be prepared by the sellers in order to deliver goods to the place of consumers.

\section{Threat (Threat)}

Internal threats to the sale of Noken, especially Yanti Noken, Siria Noken, and Noken must make innovations in the design of Noken products to make them attractive to the public as well as to compete with other Noken sales. External threats to sales of Noken are expected to take advantage of marketing Noken via online rather than using offline, because of the pandemic conditions that have hit the world and even Indonesia has not escaped this deadly virus, even Mereuka also did not escape Covid-19.

\section{Conclusion}

Application of Product Model, Price, Place, Promotion for Noken sales in increasing revenue, the model that must be applied: Application of Product Strategy Model, Application of Price Strategy Model, Application of Place Strategy Model, Application of Promotion Strategy Model. The four models must be worked on together because these models are interrelated. In this model, promotion in the midst of the Covid-19 pandemic is the most effective. Promotion that must be done by salespeople, especially online (Facebook). The seller must be responsible for bringing the order to the customer's place. The implementation of this Promotion Strategy Model must be carried out, in order to increase revenue, particularly the Merauke buying and selling forum. The price must be affordable according to the pockets of the community, and still listen to government advice to stay at home and maintain a distance.

Efforts that must be made by Noken sellers to continue to increase income. salespeople have innovative thoughts, especially from product design, the price set must also be affordable. Businesses selling Noken must take advantage of online rather than offline because the Covid-19 pandemic situation like this online can be a way out and is more economical than offline. Promotion is expected so that Noken sellers do not ignore promotions, because promotion is the spearhead of every business that wants to develop. Salespeople must frequently update on the Merauke buying and selling forum, so they can find out the orders that enter via Facebook and there must be employees who are ready to deliver the ordered goods to the consumer's place.

\section{References}

Abdurrahman, N. H. (2015). Manajemen Strategi Pemasaran. Pustaka Setia. Amstrong., K. (2016). Dasar-Dasar Pemasaran Jilid 1. Edisi Kesembilan. Erlangga.

Antonella, S. F. (2017). The Effects of Marketing Mix (4P) on Companies' Profitability: A Case Study of Automotive Industry in France. Journal of Research in Marketing, 8(1), 636-640. https://core.ac.uk/download/pdf/229163745.pdf.

Asdi, A., \& Putra, A. H. P. K. (2020). The Effect of Marketing Mix (4P) on Buying Decision: Empirical Study on Brand of Samsung Smartphone Product. Point of View Research Management, 1(4), 121-130. http://journal.accountingpointofview.id/index.php/POVREMA/article/view/93.

Borden, N. H. (1964). The concept of the marketing mix. Journal of advertising research, 4(2), 2-7. https://motamem.org/wp-content/uploads/2019/07/Borden-1984_The-concept-of-marketingmix.pdf. 
Braciníková, V., \& Matušínská, K. (2017, December). Marketing mix of financial services from the customers' perspective. In Forum Scientiae Oeconomia (Vol. 5, No. 4, pp. 36-48). http://ojs.wsb.edu.pl/index.php/fso/article/view/168.

Constantinides, E. (2006). The marketing mix revisited: towards the 21st century marketing. Journal of marketing management, 22(3-4), 407-438. https://doi.org/10.1362/026725706776861190.

Denziana, A., \& Yunggo, E. D. (2017). Pengaruh Profitabilitas, Struktur Aktiva, Dan Ukuran Perusahaan Terhadap Struktur Modal Perusahaan Pada Perusahaan Real Estate and Property Yang Terdaftar Di Bursa Efek Indonesia Tahun 2015. Jurnal Akuntansi dan Keuangan, 8(1). http://dx.doi.org/10.36448/jak.v8i1.825.

Dominici, G. (2009). From marketing mix to e-marketing mix: a literature overview and classification. International journal of business and management, 4(9), 17-24. https: //papers.ssrn.com/sol3/papers.cfm?abstract_id=1961974.

Finoti, L., Didonet, S. R., Toaldo, A. M., \& Martins, T. S. (2017). The role of the marketing strategy process in the innovativeness-performance relationship of SMEs. Marketing Intelligence and Planning, 35(3), 298-315. https://doi.org/10.1108/MIP-01-2016-0005.

Gronroos, C. (1994). From marketing mix to relationship marketing: towards a paradigm shift in marketing. Asia-Australia Marketing Journal, 2(1), 9-29. https://doi.org/10.1016/S13201646(94)70275-6.

Hadiwardoyo, W. (2020). Kerugian Ekonomi Nasional Akibat Pandemi Covid-19. Baskara Journal of Business and Enterpreneurship, 2(2), 83-92. https://doi.org/10.24853/baskara.2.2.83-92.

Kalyanam, K., \& McIntyre, S. (2002). The e-marketing mix: a contribution of the e-tailing wars. Journal of the academy of marketing science, 30(4), 487-499. https://doi.org/10.1177\%2F009207002236924.

Kartini, K. D. (2014). Pemimpin dan Kepemimpinan. PT. Raja Grafindo Persada.

Lahtinen, V., Dietrich, T., \& Rundle-Thiele, S. (2020). Long live the marketing mix. Testing the effectiveness of the commercial marketing mix in a social marketing context. Journal of Social Marketing, 10 (3). 357-375. https://doi.org/10.1108/JSOCM-10-2018-0122.

Mukarromah, S. (2018). Implementasi Strategi Bauran Pemasaran Dalam Meningkatkan Volume Penjualan Toko BajuSenamGrosir.com. (Doctoral dissertation, Universitas Muhammadiyah Surabaya).

Poluan, F. M., Mandey, S., \& Ogi, I. W. (2019). Strategi Marketing Mix dalam Meningkatkan Volume Penjualan (Studi Pada Minuman Kesehatan Instant Alvero). Jurnal EMBA: Jurnal Riset Ekonomi, Manajemen, Bisnis dan Akuntansi, 7(3). https://doi.org/10.35794/emba.v7i3.24043

Prawita, R., Swasty, W., \& Aditia, P. (2017). Membangun Identitas Visual Untuk Media Promosi Usaha Mikro Kecil Dan Menengah. Jurnal Sosioteknologi, 16(1), 27-42. https://doi.org/10.5614/sostek.itbj.2017.16.1.3

Rahmani, K., Emamisaleh, K., \& Yadegari, R. (2015). Quality function deployment and new product development with a focus on marketing mix 4P model. Asian Journal of Research in Marketing, $4(2)$, 98-108. https: //www.indianjournals.com/ijor.aspx?target=ijor:ajrm\&volume=4\&issue=2\&article=009.

Rosad, S. D. (2015). Manajemen Pemasaran. In Media.

Silverman, S. N. (1995, May). An historical review and modern assessment of the marketing mix concept. In Proceedings of the Conference on Historical Analysis and Research in Marketing (Vol. 7, pp. 2535).

Sudari, S., Tarofder, A., Khatibi, A., \& Tham, J. (2019). Measuring the critical effect of marketing mix on customer loyalty through customer satisfaction in food and beverage products. Management Science Letters, 9(9), 1385-1396. http://dx.doi.org/10.5267/j.msl.2019.5.012.

Thabit, T., \& Raewf, M. (2018). The evaluation of marketing mix elements: A case study. International Journal of Social Sciences \& Educational Studies, $4(4)$. https://papers.ssrn.com/sol3/papers.cfm?abstract_id=3173274.

Van Waterschoot, W., \& Van den Bulte, C. (1992). The 4P classification of the marketing mix revisited. Journal of marketing, 56(4), 83-93. https://doi.org/10.1177\%2F002224299205600407.

Wang, K., Wang, Y., \& Yao, J. (2005, December). A comparative study on marketing mix models for digital products. In International Workshop on Internet and Network Economics (pp. 660-669). Springer, Berlin, Heidelberg. https://doi.org/10.1007/11600930_66.

Yamali, F. R., \& Putri, R. N. (2020). Dampak Pandemi Covid-19 Terhadap Ekonomi Indonesia. Ekonomis: Journal of Economics, 4(2), 384-388. https://doi.org/10.33087/ekonomis.v4i2.179.

Yun-sheng, W. (2001). Perfection and innovation of 4P marketing mix-How to evaluate 4P marketing mix. Commercial Research, 5(6). https://en.cnki.com.cn/Article_en/CJFDTotal-BUSI200105006.html. 